This is the accepted version of an article published by Springer in Dialectical Anthropology, Vol. 40 (3), 199-220. Published version available from: https://doi.org/10.1007/ s10624-016-9432-7

Potlatch and the Articulation of Modes of Production: Revisiting French Marxist Anthropology and the history of Central Africa

Joe Trapido, Department of Anthropology and Sociology, SOAS University of London jt41@soas.ac.uk 


\title{
Potlatch and the Articulation of Modes of Production: Revisiting French Marxist Anthropology and the history of Central Africa
}

\begin{abstract}
This essay seeks to understand the potlatch as indicative of a wider category of exchange. Looking at the similarity in wild exchange rituals between North West America and Central Africa the article argues that potlatch ritual is not as an archaic remnant but a product of the interaction between capitalist and 'human' modes of production. In this dynamic 'human modes of production' (see anon) did not become capitalist, but rather there was a ritual escalation related to a series of non-capitalist imperatives based in rights in people and
\end{abstract} theatrical displays of authority. In constructing the theoretical structure used to make this case I draw on an seek to rehabilitate the work of French Marxist Anthropologists working in Central Africa, above all Georges Dupré and Pierre-Philippe Rey.

\section{Introduction}

This essay looks at wild forms of exchange in the making of the modern world ${ }^{1}$. I am calling these exchanges potlatch and in strict terms, the potlatch is a ritual belonging to certain aboriginal peoples along America's north-west coast while my particular focus is in relation to the history of central Africa. But, following Luc De Heusch (2002) and Filip De Boeck (1999), I am struck by the great similarity between certain exchange events in central Africa and the true potlatches of North America. It is central to the argument made here that the potlatch was a ritual that arose out of the interaction of two very different kinds of society - densely populated commercial civilisations (which were sometimes capitalist), and 'human modes of production' (see anon)

In examining this matrix I make recourse to the theories of 'articulation' and 'social reproduction' developed by French Marxist Anthropologists working in the 1960s and 1970s, scholars who wrote about west and west central Africa. Deeply unfashionable today, I show how their work was a far more heterodox kind of Marxism than is generally acknowledged, and argue that it still has much to teach us. I also show their

\footnotetext{
${ }^{1}$ By 'wild', I mean to exchange rituals in which huge fortunes were dispersed in competitive manner, where participants gave the impression of abandoning calibrated calculation in favour of a spirit of grandeur.
} 
limitations, giving examples of how their contribution might be built on with reference to subsequent scholarship.

Drawing on Wyatt MacGaffey's work on politics in $19^{\text {th }}$ century central Africa, I show how social dominance in pre-colonial central Africa was embedded in a set of exchanges that pervaded the whole society - encompassing not just marriage but an entire ritual nexus that was both jural and therapeutic. Social leverage also depended heavily on notions of ancestral power - the curses and blessings of the dead were crucial in sorting the slave from the freeborn. Drawing on Jane Guyer's work I show that power was also more theatrical, and more unstable, than the French Marxist Anthropologists implied.

Ultimately I suggest that the potlatch dynamic was a catastrophe that affected an entire class of societies that stood in a similar relation to the expanding commercial and later capitalist, civilisations of the early modern and modern period. Drawing on, but also taking issue with some aspects of David Graeber's (2012:127-164) fascinating theorisation of similar material, I argue that this catastrophe was the result of a complex social picture that combined demographic stagnation or collapse, massive external demand placed on economies characterised by very low productivity and harvesting from the wild, and a kind of ritual escalation caused by increased trade and the destabilisation of authority. This led to a kind of paradox where individual wealth depended on aggregate impoverishment and individual assertions of authority made authority more generally ever more fragile.

But first things first - using the term 'potlatch' as indicative of a wider category of exchanges is not new and in understanding my usage we must consider earlier theories, and look a little at the nature of the 'true' potlatch societies.

\section{Mauss and the potlatch}

In his famous account of 'archaic exchange', Marcel Mauss used a ritual common to the Indians of the north-west coast of America, known as the 'potlatch', to represent what he believed to be an entire category of archaic exchange. Many people, including many anthropologists, have come to believe that the term potlatch relates to the destruction of property, or 'fighting with property'. But both Mauss and other 
sources make it clear that destruction was just one (rather unusual) possibility. Work in the north-west American region acknowledges a competitive and destructive dimension but lays more stress on the potlatch as a form of ceremonial distribution (Roth 2002) through which individuals could accede to names that also granted ritual/political office within clans. ${ }^{2}$

These offices also granted various forms of usufruct rights, particularly to shellfish beds and salmon runs. While the abundance of the American North-West environment is often stressed, it is clear there were periods of scarcity that became particularly serious if actors were unable to acquire sufficient labour during the seasons of plenty. An important bottleneck in the cycle was in securing the labour involved in catching and preserving salmon during the winter run (Donald 1997:133-136). Wealthy 'name holders' sought to overcome this shortage via slavery. As this suggests, rights in the labour of others were crucial to accumulating material surpluses, and most north-west coast societies were divided into several classes, the basic divisions being name holders, commoners, and slaves. ${ }^{3}$ Name-holding office also granted rights in the labour of dependent kin and slaves. Slavery was probably the ultimate form of wealth, and killing or giving away a slave was a not-infrequent part of funerals and nameholding ceremonies (Donald 1997:39-40, 76-79).

As well as an exchange of goods, the potlatch was an elaborate ceremonial and theatrical event with strong elements of music and dance (Ringel 1979). This was important in several senses. First, because ownership of songs and dances, along with certain other material and immaterial possessions were integral to being a title holder (Ringel 1979:350). Second, because the name taking was validated via a spectacle. Recent authors have stressed that goods given to spectators at funerals or naming ceremonies are a kind of payment for acting as witness, and music was an integral and expensive part of the giving. Presence and receipt of payment also marked some kind of acquiescence by the demos in the authority of the title acquirer (Roth 2002:126).

\footnotetext{
${ }^{2}$ Roth argues that the 'skeleton' of the Tsimshian potlatch was in fact concentrated in funerary ritual and that the aggressive competition over accession to name was an ornamental element in the late contact period.

${ }^{3}$ The Tsimshian, for example, divided people into four classes which translate as 'real people', 'other people', 'unhealed people', and 'slaves' (Donald 1997:284-285).
} 
But this gesture towards legitimacy was also, in part, some kind of claim about access to invisible powers. The production of such abundance at the potlatch was 'proof' of access to ancestral powers (Boas 1925: 269****). In this way the performance of potlatch can be seen as a moment when visible and invisible worlds were brought together in the person of the title taker. This is quite a claim, and only a spectacular performance of distribution would convince this audience. In this context it was not enough simply to distribute blankets, or pour oil on the fire. Potlatch events were carefully staged sonic and visual performances, and without these elements the potlatch was deemed a failure (Graeber 2001: 203). It was also perhaps because of the claims involved that the theatre of the potlatch events seems constantly to hover between the transcendent and the ridiculous - another way of referring to certain potlatch rituals in Kwakwala was 'frauds' (Graeber 2001: 200).

Like most of the anthropologists of his day, Mauss saw this in evolutionary terms. To study the potlatch was to take a glimpse into our own deep past, the first stirrings of the impulse that would lead eventually to the modern contract (Parry 1986). While the concepts of prestige and 'wealth in people' of course pre-dated contact with Europeans, it seems likely that the fervid pitch and theatrical intensity of potlatching was driven by the dynamics of the trade interface. Many of the items of wealth distributed or destroyed - blankets, strips of copper, and so on - were European trade goods, obtained in return for furs (Donald 1997: 32). Several scholars (see Donald 1997: 232, 280; Roth 2002) suggest that for most of its history, the distribution/disposal element of the ritual was about validating or completing access to a quasi-hereditary title. The majority of the population had been commoners or slaves who could not aspire to titles (Donald 1997: 275-95). But epidemics of European diseases meant a great many ritual offices were unoccupied, and that a much wider pool of nouveau aspirants tried to fill these through potlatch (Ringel 1979, Wolf 1997).

Capitalist demand, in this case for furs, outstripped anything that harvesting natural systems could supply for any length of time, while competition to control the trade, and the imperative to obtain people to replace those who had died of disease, rendered war and slavery more common. In the context of radical instability, frequent and impressive displays of authority became more necessary. As the supply of animal 
pelts became exhausted in one region, trade routes pushed further inland. Slaves were traded for furs with the peoples of the interior, whose numbers were similarly decimated by disease (Donald 1997: 214--53; Wolf 1997: 191-4).

This process is far from unique. Earlier, on the east coast of America, the Iroquois 'state' seems to have undergone a similar transformation. Their 'mourning war complex', resembling a blood feud, where dead clan members were 're-quickened' by kidnappings from neighbouring groups, morphed into a system where over half the Iroquois population were in fact enslaved foreigners (Starna and Watkins 1991), while trade items, obtained from Europeans for furs - wampum, kettles, distilled alcohol (which as in West Africa probably had strong ritual connotations), guns, and clothes circulated more intensely than previously (Richter 1992: 75-104).

As we will see, there is a striking similarity between this and what was happening in Central Africa, where both war and wild, expensive rituals seem to proliferate. Like Mauss, I see the term potlatch as indicative of a wider category of exchange. But unlike Mauss I do not see the potlatch as an archaic remnant. Rather, I argue that very similar kinds of ritual emerge at various locations around the world at the point where commercial and capitalist civilisations came into contact with what I term 'human modes of production' - a phrase which, as I explain in more detail below, I apply to societies where rank and 'rights in people' are the paramount forms of wealth.

\section{Central Africa}

Many explanations have been proffered for Central Africa's particular form of insertion into the world Economy. Particularly convincing to me are explanations which stress the disruptive and militarising effects of the slave and commodity trades in the region (see Harms 1981, Manning 1990, Inikori and Engerman 1992), and those which stress the tendency for central African elites to sell the means of production, both human and ecological. In a context of relatively low demographic pressure disgruntled subordinates could simply disappear into the vast tracts of unoccupied land when things got tough, and there was little incentive to intensify production. Thus rulers saw forms of 'outsourced exploitation', notably the transatlantic slave trade, as an attractive alternative (see for example Manning 1992, 
Cooper 2000, Austin 2008, 2008a). Nevertheless, for reasons we explore in detail in the second half of this essay, such explanations are not by themselves sufficient. Elsewhere demographic collapse and war have boosted productivity and central authority - the black-death related fall of western European populations at the end of the middle ages set the scene for capitalism (Brenner 1977), while the increase in war of Europe's $18^{\text {th }}$ century greatly encouraged centralised authority (Tilly 1985).

A crucial dimension we must consider in understanding this dynamic in Africa was, I believe, the interaction of two very different types of society. And it is here that the work of French Marxist Anthropologists - and in particular Georges Dupré and Pierre Philippe Rey - is so important. But their work is now so unfashionable, and so poorly understood, that it necessitates a degree of explanation and exegesis, before it can be 'set to work' understanding the phenomena under discussion. Thus the next section will explain and justify the significance of French Marxist Anthropology (hereafter FMA), after which I will go on to look at the potlatch, drawing on what we have learned. But I hope to offer a defence of FMAs contribution without being defensive, for it is my belief that overly polemical denunciations of the school not only missed what was valuable, they also got it wrong about what they got wrong.

\section{French Marxist Anthropology a brief outline.}

In the late 1960s and 1970s a series of works were produced by French

Anthropologists, who wanted to apply Marxism to their fieldwork. With the exception of Maurice Godelier who is a case apart, in both regional and theoretical terms, these scholars did fieldwork in west and central Africa ${ }^{4}$. The most important contributions were from Claude Meillasoux and, a bit later, from Emannuel Terray in West Africa and from Pierre Philippe Rey and Georges Dupré working in central Africa. They all argued that in the more stratified parts of pre-colonial West-Central Africa a class, or proto-class, of 'elders' was dominant (Meillasoux 1960; Rey and Dupré 1969; Rey 1971). Of most interest to the material we are to deal with in this essay, both in regional and theoretical terms, are Dupré and Rey who worked in adjoining fieldsites

\footnotetext{
${ }^{4}$ Maurice Godelier was clearly a product of the same intellectual moment, but he did fieldwork in New Guinea and his theoretical matrix has substantial differences from the Africanist French Marxist Anthropology. More directly influenced by Levi-Strauss, he was less influenced by Balandier or by British Social Anthropology. For this reason I will not deal with his work in this essay.
} 
in Congo-Brazaville. Rey's early output was much greater, but they wrote between them the article that first stated the 'classic' form of 'mode of production' Marxism, in 1969.

It is worth noting, given its subsequent association with theoretical rigidity, that this was an act of heterodoxy. For Moscow and Beijing all human society passed in a strict progression from Primitive Communism, and Feudalism. Speculation about such curiosities as the 'Asiatic Mode of Production' were off-limits, as were discussions of inequality or class struggle in other, more varied, social forms (Bloch 1985).

Dupré and Rey's (1969) arguments about the 'lineage mode of production' then departed radically from all 'party lines', and also from the speculations of Marx or Engels about pre-capitalist societies. They depicted a society where the dominance of elders (mbuta) - was based in their rights over the labour of others - slaves of both sexes, most women, and male 'cadets' (lekie) - dependents who were held in various states of social immaturity. These elders appeared to have no very strong control of the means of production - land was plentiful and the chief factor of production was the labour of the young. They nevertheless managed to enforce their dominance via their control over 'social reproduction'. This was affected through exchanges in prestige goods. Such exchanges determined the destinies of slaves, women, and cadets, and were pivotal in allocating labour between corporate groups. The prestige goods were obtained from European merchants at the coast in return for various commodities - including slaves, ivory, and rubber - through chains of exchange monopolised by elders.

Thus, via 'articulating' between the 'capitalist mode of production' and their own 'lineage mode', the elders were also able to control the surpluses others produced, extracting tribute or labour from subaltern groups by manipulating an ideology of descent - where subalterns were defined as junior relatives - and holding out the promise of social advancement to a select few. Thus, contrary to Adam Smith, but also to the vision of capitalism 'battering down all Chinese walls' in The Communist Manifesto, increased trade did not necessarily undermine pre-capitalist economic dynamics. In fact it often reinforced them. 
This is not a popular mode of analysis today. One line of attack, associated particularly with the historian EP Thompson (1978) was that such work was simply bad philosophy, and he assumes that his remarks about Althusser will apply to a broad category of scholars who he terms 'Althusser's progeny' ${ }^{5}$. Setting aside the validity or otherwise of Thompson's remarks about Althusser, as a wider critique it is misplaced. FMA drew some important insights from Althusser, but their frequent references to his thought are better viewed as professions of allegiance ${ }^{6}$ than as an accurate intellectual genealogy. That is to say that Althusser was a far less important influence on their thinking than either they, or their enemies, conceded. Likewise their caustic remarks about 'bourgeois' scholarship can persuade the casual reader, unfamiliar with a certain rhetorical style, that their work had taken little from previous forms of anthropology. This was far from the truth.

Emmanuel Terray recounts an anecdote about how, during his time at the Sorbonne, Africanist Anthropology there was dominated by the school of Marcel Griaule, who had written about the religious beliefs of the Dogon in Mali. Terray comments that the members of this school were too interested in cosmology and in the discourse of a few ritual specialists and not interested enough in what ordinary people actually did.

'[a then eminent member of Griaule's school commented] "the English are interested in what people do, but what really counts is what they say", too timid to say so, I then felt myself to be profoundly British.'

Terray (1986:10 my translation)

As Terray's quote suggests, FMA owed much more to Anglophone Social Anthropology than is generally realised. Their greatest immediate intellectual influence was not Althusser, far less Levi-Strauss, but Georges Balandier, under whom Meillasoux, Terray, Dupré and Rey had all studied. Balandier was himself highly influenced by British social anthropology - particularly the Manchester School

\footnotetext{
${ }^{5}$ His only specific references to empirical scholarship are to the works of Hindness and Hirst, whose work was seen as strange and extreme by just about everyone, including writers not unsympathetic to Althusser (Anderson 1980).

${ }^{6}$ Though politically speaking Terray and Rey were quite far from from Althusser - they were more enthusiastic about China and about 1968 - and took more distance from the French Communist Party.
} 
- and he encouraged his students to explore this. The other great influence that emerges from actually reading the FMAs, is of Polanyi, Bohannon and substantivist Anthropology generally. This is not immediately apparent, in part because Dupré and Rey spend so much time attacking the substantivists (e.g. Dupré and Rey 1969: 143), but their account of exchange is heavily indebted to them.

Some of this might seem to lend credence to another line of attack, that FMA simply reproduced the "functionalist' ${ }^{\text {' }}$ - broadly Durkheimian - social anthropology it claimed to have replaced (for example Kahn and Llobera 1980). But this accusation is problematic in several ways. First, because it implies that classic social anthropology was some sort of intellectual disaster, and, second, because it ignores the very real advances made by French Marxist scholars. Where Mary Douglas or Evans-Pritchard had asked as 'How does the system function?', Meillasoux took this a stage further by asking 'function for whom?' (see also MacGaffey 1985: 52). Where substantivist anthropology had proposed a sphere of exchange controlled by 'elders' (Bohannon 1959), here elderhood was conceived of as biological category whereas for Meillasoux it was an interest group ${ }^{8}$. Meillasoux was not the first anthropologist to posit an element of disharmony in non-capitalist societies (for example Leach 1954; Barthes 1959), but his model, which suggested a role for interest groups within a way of life, rather than a series of games played by individuals 'maximising' their power, was distinctive and convincing.

Meillasoux thus went beyond the confines of both traditional Marxism and liberal social science - both of which, for different reasons, were resistant to the concept of class struggle in non-capitalist places (see also Bloch 1985). In this sense criticism of 'functionalism' in Meillasoux is anachronistic, in that he is often attacked for

\footnotetext{
${ }^{7}$ Some objections to functionalism are simply an objection to functional explanation - explanations where the intended effect is used to explain the act that causes it. Such arguments are well summed up in the debate between Cohen and Elster (see Cohen 1978, 1982). As Cohen shows, the consequences of denying something like functional explanation a major role in social explanation are fairly extraordinary, and the notion of 'feedback mechanisms', advocated by Elster and subsequently by others is far more problematic than they realise.

${ }^{8}$ Mary Douglas, who drew on substantivist anthropology (Bohannon's work on Tiv exchange) to theorise the way that elders monopolised exchanges of raffia cloth among the Lele specifically compared raffia cloth exchange to the wartime rationing coupon - the second world war in the English imagination being a time of unparalleled social cohesion, remembered fondly by high Tories like Douglas and by social democrats alike.
} 
intellectual errors that he was instrumental in pointing out, even if he did not completely make the break with earlier modes of analysis (see Donham 1999: 78). I think this functionalist tag is even more inappropriate when applied to the work of later French scholars in the Meillasoux tradition, Rey and his colleague Georges Dupré (see, for example, Dupré and Rey 1969; Rey 1971; Dupré 1985).

Kahn and Llobera, speaking of French Marxist anthropology, state that 'these writers appear to share the view that "societies" as conceived by traditional anthropology are relevant units for analysis' and 'other concepts such as "lineage" have also been accepted and widely used without serious epistemological critique' (1980: 88, see also Hann and Hart 2011:76). But in fact Rey's analysis challenged all of these concepts (1971: 243-5), and he explicitly argued that descent was an ideology. He gave a plausible account of how the lineage was not based in quasinatural principles of descent and segmentation. Lineage histories were rather made up to suit political exigencies in the present (see also MacGaffey 2000: 57 and Dupré 1985: 83), and most members of a lineage were not biological offspring, but people who were absorbed via obviously political processes like slavery or patronage. For Rey the lineage was an ideological form that allowed a certain class of people conceived in local terms as 'elders' - to control and exchange rights in other people slaves, women, and cadets.

Another common criticism of French Marxist Anthropology was that it pushed a kind of naïve, object-based materialism. Graeber (2006) says:

The ultimate weakness of Mode of Production approaches, it seems to me, is that they begin from a very naive sort of materialism. 'Material production' is assumed to be the production of valuable material objects like food, clothing or gold bullion; all the important business of life is assumed to be moving such objects around and transferring them from one person or class to another. (2006:9)

Graeber uses this characterisation as a foil to his own, very stimulating discussion ${ }^{9}$, and as such it can be forgiven as a useful heuristic, but in terms of intellectual history

\footnotetext{
${ }^{9}$ In this way Graeber's central idea - that modes of production should be considered as producing people as much as objects, is far closer to that put forward by Dupré and Rey (1969) than he is aware.
} 
this is quite wrong. In Meillasoux's and Dupré and Rey's original discussions the success of powerful lineages lay in winning and retaining social subordinates. This relied on exchange - in such exchanges 'things' could important, but the thing that was being exchanged above all was people.

\section{Social Reproduction and social change}

Dupré and Rey (1969) proposed a notion of social reproduction that incorporates and is able to account for change. The possibilities for social reproduction were seen to have varied over time and the thing reproduced was not 'the social structure', but positions of advantage in a set of unequal power relations. Contrast this with the theory of reproduction put forward by Jack Goody (1958), whose discussion has influenced subsequent Anglophone anthropologists (e.g. Comaroff and Comaroff 2004). Here the thing reproduced is the domestic unit and a series of heritable roles linked to a biological life cycle. As this implies, while this more recent writing on social reproduction has the sheen of the anthropological cutting edge, the notions of temporality involved make no advance on the ideas of the Manchester school. Change in the present is acknowledged, but only against the background of the static millennia stretching back into the African past. Thus conflict related to social reproduction must be linked to various kinds of recent crisis, a crisis which implies a prior and more benign state of stasis (Comaroff and Comaroff $2004^{10}$, clearly drawing on Gluckman 1963).

The problem with this is that while various recent political and economic events have certainly been experienced by people as a crisis - crises are the stuff of history in Central Africa as much as elsewhere. And there is considerable continuity in the way in which the powerful have used social reproduction to maintain their position in the face of such events. Indeed, as Naomi Klein (2007) points out (albeit in a rather

\footnotetext{
${ }^{10}$ Such a notion of crisis involves attributing multiple social phenomena to recent conjunctures, when they are in fact not new at all. Thus the Comaroffs argue that the 'chronic unattainability of material independence ... [which] means not being able to marry or have legitimate offspring...' or that 'strategies to seize control of the terms of trade...has itself become pivotal dimension of efforts to redress crises of social reproduction' (Comaroff and Comaroff 2004:338-343). Looking at the work of Dupré and Rey we can see such strategies are rather an essential element of the longue durée. Scholars such as McNeil (2011), while they cite the work of the Comaroff's, seem to have re-invented for themselves something more akin to Meillasoux's formulation.
} 
different context) the ability to use ideological levers to turn crisis to your advantage is one of the key attributes of successful ruling classes. For this reason the model which both Rey and Meillasoux proposed was a real advance, in that it recognised that social reproduction has always been problematic - a mechanism for recreating not society but class power, and a site of struggle across the longue durée.

\section{Regional Specialists}

A further problem with critique of FMA has been the fact that the focus of the original debates was West and Central Africa. ${ }^{11}$ The harshest criticism has generally been restricted to quite broad philosophical arguments. Discussions by regional specialists, who were able to engage with the details - for example Jane Guyer (1993) or Wyatt MacGaffey $(1986,2000)$ - were far less polemical, and yet at the same time these scholars far more effectively identified areas of the FMA argument that were problematic.

Thus Wyatt MacGaffey's work on ritual and power can be seen as a useful corrective to the over-strong focus on marriage exchanges by FMA, a focus that probably reflected the influence of Levi-Strauss, who, famously, saw the exchange of women between groups of men as the foundational act of society. But it almost certainly also reflected 'the facts on the ground' as they had been re-cast by colonialism. In the colonial period marriage was the primary site of African lineage elders' power, with male African power structures being reduced and reconfigured within the domestic and rural settings assigned to them by the coloniser. MacGaffey's studies point to a much wider jural/ritual nexus within which exchanges took place. There is description of a wider set of exchanges in FMA, especially in their longer treatments (e.g. Rey 1971), but I think it is fair to say that FMA placed too little emphasis on this wider conception. For it was this complex ideology, rather than the narrower set of exchanges foregrounded by the FMAs, that was essential to making up the class power of the elders.

Jane Guyer's seminal (1993) essay on exchange in what she calls Equatorial

\footnotetext{
${ }^{11}$ This is another area where Graeber 2006 displays some unfamiliarity with the nature of the 1970s Mode of Production debates - he implies that discussions of non-state societies were peripheral to this discussion when in fact they were foundational and central.
} 
Africa, includes a respectful discussion of FMA's contribution, but she identifies some even more crucial issues. The first is that the region has been the site of intense political turmoil, with radical instability in the value of people and things. Given this radical instability, the efficacy of 'things' - currencies and other valuables - as a mechanism of social control appears as 'a problem to be explained, rather than a premise to be claimed' (Guyer 1996: 245). Guyer then goes some way to solving the problem she has identified. Exchanges were not mechanical rituals with precisely quantified amounts of social currency. They were unstable performances where the outcome was not certain. In such performances the fates of the 'little people' were sealed, but at the same time the persons of elites, and aspirant elites, were adorned, ranked against one another, glorified and assigned value. In a system where people were the ultimate form of wealth, 'wealth in things' was an essential adjunct to creative theatrical performances designed to establish the wealth and status of individuals in unstable circumstances. This insight - that power was much more theatrical, and more aesthetic, but also wilder and more unstable, is at the heart of my discussion here.

Nevertheless, it is also the case that Guyer (and others such as Barber 2007, who flesh out this picture of creative performance as the route to social status) does not pay enough attention to the fact that such valuations, unpredictable as they could be at the level of individuals, never floated clear of the capacity of a categorically distinct class of elders to extract surpluses from subordinates. Furthermore, rather as Foucault's observes in his discussions of mediaeval forms of power in Europe (Foucault 1998) while the bodies of the elite were singularised, and rendered glorious, so the persons of social juniors were construed as nameless, worthless, invisible and disposable.

\section{Articulating}

Criticism of Rey and Dupre's notion of 'articulating modes of production', where capitalist merchants intersect with lineage elders, is in some ways understandable. It is a model of how society works and, like all models, there is a strong temptation to reify the model and forget the complex reality it represents (see Jewsiewicki 1985). But once again, attacks generally present the crudest, least convincing version of the theory, rather than dealing with the arguments made at their strongest. In the earlier formulations, which deal exclusively with Central Africa, above all Dupré and Rey 
(1969; see also Rey 1971 and Dupré 1982), these put forward quite a subtle idea of articulation, as a product of multiple weakness - the merchants' inability to penetrate the interior, and the elders' inability to exploit the cadets beyond a fairly narrow set of limits. This offered a way of thinking about the effect of capitalism on non-Western peoples, without ignoring the internal dynamics of non-capitalist societies and without depicting the capitalist mode of production as all-powerful.

In Rey's ambitious later work Class Alliances (1982/1973) - which attempts to formulate a theory of modes of production more generally - much of this subtlety is lost. The capitalist mode of production is depicted as a coherent entity with functional needs and what, at times, seems to be a directing mind. Thus capitalist mode of production of the 1970s that Rey describes, deliberately delays its extension into the third world because of the threat of social revolution that would be posed by transformation. But my intention here is to hold on to the central insight of Dupré's and Rey's earlier and more empirically detailed works - that capitalism did not 'take' well at all in many parts of the non-European world. Furthermore, that most of the interactions between an expanding Europe and non-western peoples were interactions where the two sides wanted different things and had very different political and economic systems.

I have argued that the depiction of FMA as excessively theoretical was a partial view, and that a sympathetic revaluation of their work, which was open and nondoctrinaire in its influences, could make a real contribution. But the usefulness of such theories cannot simply be established via abstract debate. With this in mind the second half of this essay is devoted to a rough sketch of what this kind of approach might look like.

\section{The potlatch and the expansion of Europe - the outline of a theory}

In his wonderfully negative polemic, The Invention of Primitive Society (1988) Adam Kuper dismisses any attempt to impute similarity between peoples based on epochal characteristics. In strictly empiricist terms we cannot know a great deal about the thoughts of non-literate people who have not had contact with us, and who, we can assume, had their own histories and traumas before the modern period. But, even 
if we were to accept this rather extreme form of empiricism ${ }^{12}$, we would still be in a position to make some inferences about these peoples. For when they did start to come into contact with Europeans various 'primitive' peoples around the world interacted with commercial civilisations in strikingly similar ways. It is thus the argument here that it is valid to infer that this similarity in their responses arose from the fact that they were starting from comparable situations.

This leaves a terminological issue. Various names have been given to such forms of human organisation: savage, primitive, stateless, acephalous, lineage-based, and so on. For various reasons all of these designations are unsatisfactory. 'Savage' and 'primitive' are hoplessly value-laden - might one not argue that avoiding the personality cults, coercion, and savage economic stratification of centralised states constitutes a form of sophistication? 'Stateless' and 'acephalous' refer only to an absence of the state, not to any positive qualities such places may exhibit. In any case, certain societies on this model did form quasi-states, among them the Iroquois confederacy, the Kuba 'empire', or the 'kingdom' of Kongo. 'Lineage-based' and related terms draw attention to kinship. But even if you accept, as I do, that kinship is not entirely the invention of Western anthropologists (contra Kuper 1988, see MacGaffey 2005), it seems that not all of these places used descent as an organising principle. A further problem with anything similar to the 'lineage mode of production' as a general term is the confusion this would generate; Dupré and Rey's usage refers to a specific West-Central African configuration.

It is notable that in the case of capitalism, Marx defines the mode of production by the primary form of accumulation - capital - and here I follow the same principle. As I argued in the introduction, in the mode of production under discussion here the primary site of accumulation is 'wealth in people'. David Graeber (2011), following Polanyi calls these societies 'human economies', ${ }^{13}$ a designation that recognises the fundamental object of exchange and accumulation in these places - people. To incorporate this insight within my wider theoretical vocabulary I am calling these

\footnotetext{
12 While rhetorical attacks on 'empiricism' (bourgeois or otherwise) can be tiresome, here they may be in order.

${ }^{13}$ Graeber's nomenclature follows Polanyi but I think he is more aware of what is actually distinct about these economies. Guyer's (1993), who is clearly also influenced by Polanyian Anthropology, adopts the term 'wealth in people' which is also related.
} 
social arrangements 'human modes of production', a broad category of which Dupré and Rey's 'lineage mode of production' is clearly a variant. The term 'human mode of production' also recognises the debt of this theoretical approach towards substantivist anthropology.

And yet while I am influenced by Graeber's 'human economy' I believe that his theorisation draws too uncritically on classic anthropological texts - notably Mary Douglas on the Lele (1968). Graeber presents the Lele as a kind of baseline, against which the slave-trade induced depravity of other human economies can be measured. In this pre-Lapserian state, human economies kept a strict divide between people and things. Slavery - where people and currencies could be equivalent - existed as a dangerous precedent, but for the Lele it was marginal and categorically distinct from the wider game of exchanges in people, often referred to in Africanist literature as pawnship. Furthermore according to Douglas's informants, the Lele only enslaved war captives. That is to say, unlike reports from almost all other parts of central Africa, they did not enslave those who had lost out most badly within the exchanges that characterised the lineage system.

But all of this relies upon us accepting some very problematic assertions in Douglas' monograph - based on the kind of ahistorical scholarship that the FMAs had sought to supersede. I am unaware of any detailed histories of the Lele, but more general works on the Kasai region leave little room for doubt. By the mid- $19^{\text {th }}$ century the region was deeply enmeshed with the hugely violent Luso-African and Swahili trades, which combined a vigorous internal slave trade with ivory and rubber exports $^{14}$. The (highly intrusive) Belgian colonial context is similarly absent in Douglas' work in a way that is relevant to Graeber's conclusions about slavery vis-àvis other forms of rights in people. Despite the Belgians' own involvement in a succession of forced labour regimes, they used the suppression of slavery as the preeminent ideological justification for their mission civilisatrice. In this context the

\footnotetext{
${ }^{14}$ Kasai rubber was among the most highly valued in central Africa, while Cokwe hunters connected to the Portuguese at Luanda drove elephant herds ever further north to the Kasai river. Early Belgian colonialism in Kasai continued the violent 'capita' system used by the Luso-African trade, where merchants armed local intermediaries who set of on militarised trading parties. Vansina's (2010) detailed history of the Lele's immediate neighbours leaves one of little doubt about involvement of the region in a series of brutal trades, ultimately connected to the Indian and Atlantic oceans, in the second half of the $19^{\text {th }}$ century.
} 
insistence by Douglas's Lele informants that pawnship - which was still openly practiced - was categorically distinct from slavery ${ }^{15}$ - which was heavily suppressed cannot be taken at face value. Fear of the colonial authorities, not Arcadian isolation, may explain why the Lele appear so different.

\section{Trade and articulation.}

Most European merchants were seeking to acquire various raw materials from the interior of other continents - such as furs, slaves, ivory, spices, or precious metals. But what did their non-European trading partners want? Sometimes they traded their wares for things like shells or bits of metal that had worked as currency before the new traders arrived. In these cases European merchants were sometimes able to use their wider reach to source these items more cheaply, as in the importation of shell valuables into West Africa. At other times the Europeans, or their diseases, had wiped out the coastal peoples who had supplied the valuables before - as in the case of wampum (sacred shell beads) in America. ${ }^{16}$ Other goods carried by Europeans in trading with human modes of production seem more diverse, though certain themes do recur - firearms, distilled alcohol, textiles, forms of glass and ceramics. Invariably these European goods displaced or demoted items of local manufacture as objects of prestige and in systems of social currency. A detailed enquiry into why this should have been the case is beyond the range of this study, but clearly metaphysical aspects were in play, and imported goods were often associated with legitimating supernatural powers (Bernault 2006; MacGaffey 2000). At the same time the imports were generally manufactured goods from places capable of a quality and scale of production that the local economy could not match.

The introduction of these goods did not alter the fundamental dynamic of these

\footnotetext{
${ }^{15}$ A clandestine indigenous trade in slaves, especially in female slaves continued well into the 20th century in many parts of the Congo, and this was certainly true for the Bakuba, the immediate neighbours of the Lele. The comment in Vansina's (2010) book that a Lele healer 'accompanied by his slave' (2010:241) ministered to the Kuba king Kwet Mabinc (1919-1939), implies that this was also the case for the Lele. In matrilineal societies, like the Lele, one of the main attractions of female slaves was that their children's labour would belong to their father, rather than, as was the case for free wives, to the maternal uncle. Vansina also states that the children of pawn wives among the Bushong (the central ethnicity in the Kuba polity who were also matrilineal) - owed part of their labour to the husband implying that they were somewhat comparable to slave wives (Vansina 2010:241).

${ }^{16}$ In fact, while some form of shell valuable had existed before, 'true wampum is a cross-cultural product of European-Indian contact for it could be made only with iron tools' (Richter 1992: 85).
} 
systems; rather, it added momentum to the existing, internal set of trade relations, which were invariably linked to acquiring rights over people via control of social reproduction. This increased momentum of trade concurrently undermined local systems of production, through increases in disease and slavery, and also by intensifying political and military ferment. Why this happened is not self-evident. Adam Smith's belief that 'the propensity to truck, barter, and exchange one thing for another' (Smith 1776/2000:7) leads to a greater and more productive division of labour is still an axiom of modern economics, while recent historical sociology (for example, Tilly 1985; Ferguson 2002) has suggested that in Europe the wars of the eighteenth century were in fact laboratories of the state, where central devices of modern administrative power were developed.

Clearly the prior development of productive powers is key to these divergent outcomes. Tributary states and human modes of production were pushed in opposite directions by their interaction. Slave labour from Africa allowed Britain to run regimes of 'extended primitive accumulation' in the Americas, sustaining a transition to capitalism that might otherwise have foundered during the frequent reversals of the early industrial revolution (Blackburn 1997: 509-73). The polarising effect was also political-economic. In Western Europe new forms of more costly and technologically demanding war entailed new forms of raising money that would not undermine the economic production needed to pay for these vast mobilisations. In a variety of ways - tax farming, government bonds, the grand bargain between accountable legislatures and taxable populations - they found powerful new mechanisms that allowed them to pay for military campaigns and, as a by-product, dramatically increased the revenueraising capacity of central authority (see Tilly 1985).

Human modes of production were capable of considerable brutality but, even at their worst, the wars of the seventeenth and eighteenth centuries in Africa and the Americas were far less violent than European conflicts of the time - battles in Central Africa, as in North America, seem to have resembled a form of ritualised kidnapping and were generally abandoned after a handful of casualties (MacGaffey 2000; Richter 1992). It was not, then, the savagery of war where Human modes of production were disadvantaged - European wars of the period were probably more violent and more destructive of productive infrastructure than conflicts elsewhere. 
Rather it is in the way that political entities financed conflict and authority more generally where differences can be observed that seem to disadvantage human modes of production. In Africa and the Americas the resources underwriting authority were sought via an orientation to the outside world ('extraversion' in African studies jargon) and were paid for in ways that undermined the productive powers; such resources included the guns that became increasingly important in war, and also took the form of legitimating ritual, which involved display and dispersal of imported prestige goods. Such problems of authority pre-dated but were also exacerbated by the interaction with Europe.

'They gave us six fishhooks

And two blankets embroidered with smallpox'

(from Paul Muldoon, Meeting the British, 1987)

People and the bounty of the natural environment were clearly the pre-eminent factors of production in these low-tech, agrarian societies. Populations which were (probably) sparser than in non-Russia Europe to begin with (see Austin 2007) and were already severely affected ${ }^{17}$ by disease and low fertility caused by European encroachment - were also sold on to raise capital, while the other trade goods which

\footnotetext{
${ }^{17}$ Population figures for America and Africa pre-1500 are very speculative. 'Respectable' estimates for the population of the pre-Columbian Americas range between 14,000,000 and 117,000,000 (see M.White 2011 for overview). Even were it the case that there were areas of very dense populations in the Americas, it is certain that disease had a huge impact on these areas. The pre-contact Pacific northwest (which was an incredibly bounteous area) clearly had unusually high populations for a nonagricultural society, but it is also clear that these populations suffered catastrophic declines (Boyd 1999). Africa was probably more densely populated than the Americas, but the evidence tends to show that it was considerably less populated than Europe - Thornton's (1977) estimate of population densities in the Kingdom of Kongo arrived at a figure of 4.1 people per square kilometre by the beginning of the $18^{\text {th }}$ century, While Manning (in Austin 2008a) estimates densities in 1750 of 2.3-3 per kilometre for tropical Africa, this is to be contrasted with non-Russian European population densities in 1750 of around 23-27 per kilometre (Thornton 1977; Austin 2008). African populations south of the Sahara were flat during the $18^{\text {th }}$ and $19^{\text {th }}$ centuries according to respectable guesstimates e.g. Durand (1967), Manning (1990:70-71). Manning's more detailed and regionally informed guesses suggest that populations fell in West Central Africa during the period 1750-1850. This needs to be set alongside the widespread adoption of neo-tropical food crops in Africa, which would have increased food security (Austin 2008) and in other parts of the world contributed to large population increases during this period. A further problem with this 'data' is that it is hard to see how these slave trade focussed estimates square with the sleeping sickness and 'red rubber' mortality and population estimates, which cover Central Africa from the 1860's until around 1910. Both Manning and Durand indicate a modest recovery or stabilisation of the population just as other scholars say it was entering a period of catastrophic decline.
} 
capitalism demanded of human modes of production were reliant on the harvesting of natural systems until their collapse.

In the case of wild rubber harvesting, which occurred in the interregnum between the invention of vulcanised rubber in the late 1840 s and the maturation of rubber tree plantations in Malaya in the twentieth century, we see another example of the 'extended primitive accumulation' model Blackburn uses to understand plantation slavery. Rubber extraction in Central Africa, and the extreme forms of attendant violence it caused, reached their apogee under the Belgians, but were well under way before their arrival. Beginning in the gallery forests of northern Angola, the trade pushed up into the Congo Basin, drawing on the same classes of Kongo, Ovimbundu, Bobangi and Swahili intermediaries who were involved in trades for slaves and ivory. The disruption, increased interconnectivity, and violence of these trades led to huge increases in disease - notably sleeping sickness, venereal disease and measles - and disease and stress related sterility, as well as falls in food production. This caused very significant falls in the population in parts of Central Africa, persisting well into the twentieth century (Harms 1981; Vos 2003; Vellut 2004; Horchschild 1998; 2005, 2006; Roes 2010; AM.White 2011) ${ }^{18}$. The difficulty of supplying the exponential growth in capitalist demand from a forest product meant that the trade involved ever more violent pressure on non-capitalist peoples to fill in the gaps, while a fully capitalist system based on plantation arboriculture established itself. ${ }^{19}$ This was not a system that allowed for any sustained accumulation of power or wealth within Central Africa.

In this way human modes of production appear to have become locked into a dynamic, reinforced by the European merchants, where individual prosperity conceived of as rights in people and dispersals of wealth over retinue - became dependent on aggregate impoverishment - via selling, or pushing beyond breaking point, the means of production. As we can see this account does not espouse the view, proposed by the cruder forms of dependency theory, that Africans were cheated of their birth-right in exchange for valueless trinkets. At some points in the last 400

\footnotetext{
${ }^{18}$ How significant is the subject of huge controversy. Aldwin Roes (2010) is a fine overview of a vexed issue.

19 This was especially true in the case of African rubber, which was not tapped as it was in the Amazonian case, but harvested from creepers and involved killing the plant.
} 
years, above all during the eighteenth century, Africans were able to obtain high prices for their commodities (Eltis and Jennings 1998), and indeed such high prices are a part of our story. Prices paid for African commodities took the form of huge importations of European manufactured goods. The vast importations of goods into Africa ${ }^{20}$ produced a singular set of effects that are still felt in the forms of political subjectivity found in Africa.

A series of trades emerge in the pre-colonial period - slavery, ivory, rubber - that supply the escalating demands of capitalism, but also drive forms of ritual escalation within human modes of production. As the capacity of peoples near the coast to supply the goods required by capitalist traders is exhausted, political systems there become ever more structured around their role as intermediaries with the interior. In the process, some political and economic formations like the kingdom of Kongo are undermined, while others emerge - like the kingdom of Luango, the Portuguese enclave around Luanda, Ovimbundu middlemen, aLuund warriors, Tio trading intermediaries, or Ubangi boatmen. Chains of exchange push inland as more and more people are drawn into the orbit of the theatrical and prestigious cultures of the coast (see Dupré and Rey 1969; Harms 1981; Velut 2004).

As in the societies of the northwest of America, social control in pre-colonial Central Africa was embedded in a wide nexus of jural, therapeutic, and funerary ritual, all of which involved exchanges of rights in persons, often for prestige goods. In this context the blessings (and curses, which are often formally identical) of the elders took on an existential significance for all social juniors ${ }^{21}$ - slaves, women, and cadets. Without the active protection of several elders - four 'chiefs' in the case of the lower Congo (MacGaffey 1986: 32) - who could intercede with and provide the resources to pay fines incurred by near inevitable ritual infringements such as stepping on the shadow of the chief's concubine (ibid.: 36 ), the vulnerable could easily find themselves reduced to slavery. Meanwhile title holding 'made possible a

20 For example, for much of the eighteenth century Africa, along with the West Indies, was the main market for British textile exports (Blackburn 1997: 522).

21 Blessings were often conceived of as a transfer of ancestral substances, stored within the person, and, just as the vomit of nobles was sacred in the potlatch cultures of the Americas (Walens 1981), here both the breath and spittle of elders take on a sacred quality. 
continuous income' and 'organised a flow of wealth upward from poor to rich' (ibid.: 36). It is worth underlining once more the similarity between this form of social organisation and that found among the true 'potlatch' societies of the north-western coast of America, as this description of enslavement in the latter makes clear:

The miscellany of causes for enslavement within one's local group suggests that the very poor might easily find themselves in a position where they could not meet some imposed financial obligation and, lacking the protection of powerful kin (probably the definition of very poor in this culture area) were then subject to enslavement.

Donald (1997: 120)

Elders on the lower Congo could also draw on their stock of trade goods to buy further titles, which offered further gatekeeping opportunities. Participation in rituals and institutions which granted prestige, office, and legitimacy all required a supply of trade goods - whether in acceding to public office as a 'chief', or undergoing initiation into mystical societies that doubled as cross-ethnic trading associations (see Janzen 1982).

As in the societies of North-Western America, funerals were probably the dominant ritual with notions of succession and the assertion of the temporal and supernatural powers of the deceased's lineage being important in both places. As accounts make clear, the funerals of notables required vast expenditure - grave goods including toby jugs and china dogs from Stoke on Trent, vast quantities of food and palm wine served to guests and poured out in libations, explosions of gunpowder, and slaves who would be strangled or simply thrown live into the grave ${ }^{22}$ (Laman vol ii 1953-68:85-90; Dupré 1985:184-201). Most strikingly, the corpse itself would be wound in imported red cloth - cloth which was used as a form of money - until the bundle was enhanced to massive proportions. The relatives of the deceased would dance with this great burden to the grave. And it is clear that dancing was not an

\footnotetext{
${ }^{22}$ Vansina (1978:181) notes that for the Kuba, human sacrifice at funerals bcame more common in the late nineteenth century as a result of Luso-African trade, with one report of 'a thousand slaves' killed at the death of a queen mother.
} 
incidental feature of such events. Music and dance recur again and again in the nexus of jural, funerary, and therapeutic exchanges. ${ }^{23}$

\section{Fetishism: ideologies of generation and the dead}

This obsession with the dead brings us to a final aspect of Marxist theory. For Marx the capitalist mode of production depended not simply on material circumstances but also on a specific form of ideology that fetishised capital and commodities divorced from the wider relations of production, such that it appears as 'money that begets money' (Marx 1867/1961:155). Marx himself asserted that, in precapitalist modes of production people were not mystified about the sources of value, and that social relations were simply sustained by violence. I believe this is unlikely, and that historical and ethnographic evidence from central Africa points in a different direction. Just as the capitalist mode of production fetishises capital ${ }^{24}$, so the human mode of production fetishizes certain powerful persons.

Graeber's description of Lele exchange takes to the heart of the matter. Noting the hierarchical nature of gift exchange - where gifts of raffia cloth flowed upward from the cadets to the elders - Graeber notes 'it never occurred to those receiving [raffia cloth] that they should have to reciprocate in any way' (p138). This accurately encapsulates Douglas's ethnographic account, and is, broadly speaking, also true for the FMA accounts ${ }^{25}$.

But the ethnography of the region, viewed more broadly, shows that in the local conception, cadets are explicitly seen as indebted to the elders. Much of this was related to the skilful manipulation of prior surpluses by the elders of course, but this cannot be separated from a second, purely ideological factor. Everywhere one looks in

\footnotetext{
${ }^{23}$ This nexus of material and musical/kinetic ideas of power is noted by Guyer, speaking of the Igbo, along the coast of Atlantic Africa (2004: 78): 'Proximity of ones most valued self to the ancestors was courted in dance and ritual. In dance one could cross over the thin line between this world and the spiritual world... [while] title objects were stored in the rafters close to the ancestral shrine, along with all the important items that extol the force of individual status....'

${ }^{24}$ The term commodity fetishism is widely used, by Marx and others, but Marx makes it clear that it is in capital itself - represented by its adherents as 'money which begets money' or 'portion fructifiante de la richesse' (1970: 15; 1990: 523) - that fetishism is most entrenched, and most central to capitalism's self-understanding (see also the discussion in Volume 3, Marx 1895/1991).

${ }^{25}$ In the mongraphs of both Rey (1971) and Dupré (1985) there are certainly discussion of metaphysical beliefs about the power of the elders in relation to the dead but it is not made as central as it could be.
} 
central Africa elders (and the powerful more generally) are seen as receptacles of ancestral substances from the land of the dead (see particularly MacGaffey 2000, Warnier 2007). Substances connected to the bodies of elders via a series of metaphorical connections - spittle, white clay or chalk, breath, palm wine imbibed and then spat out - are conceptualised as a kind of blessing. These blessings from elders to the cadets are believed to be necessary to any kind of social flourishing, but are also everywhere a formal part of the work of allowing or retarding social reproduction, and ultimately in sorting the slave from the freeborn. The child whose head is not spat on by the elders (a traditional form of blessing) is designated a slave, one who accedes to ritual title has chalk or white clay applied to their eyes by the elders (allowing them to see the world of the dead), etc.

These ideas of invisible exchanges were everywhere in the region enmeshed with the elders' real dominance over certain prestige goods/social currencies, and indeed the distribution of goods by elders was invariably presented as the emanations of their more general munificence. Far from making a distinction between people and things for the purposes of exchange, as Graeber (2012:133) contends, the persistent ideological schema one finds throughout central Africa makes a series of divides that defy this kind of categorisation. Powerful chiefs - but also assorted magical objects were vessels 'animated' by powerful substances from the dead. The flow of material goods, success in the hunt, or the harvest could all be taken as outward sign of this metaphysical abundance. Social inferiors by contrast were perceived as empty vessels: 'mutu pamba' (vain/empty men), as they were known on the $19^{\text {th }}$ century lower Congo, and as they are still called in Kinshasa.

Just as under capitalism money and commodities are cast as producing wealth in and of themselves 'as a pear tree produces pears' (Marx 1991: 516), so in the human mode of production the bodies of powerful people were fetishised as generative divorced from wider relations of production, powerful people were seen as creating the wealth and fertility they had appropriated.

Given that Marx's use of the term fetishism is an ironic subversion of earlier, derogatory theorisations about the fetish as a mental crutch for the primitive mind (see Pietz 1985) it is worth pointing out that central Africans were never trapped in a state 
superstitious dread by this ideology - the legitimacy of exchange was often challenged - revolts by obstreperous youths, slave lineages, or new cults are a constant theme in the history of the region. But within a political economy ever more based around pillage, this chronic lack stability also led to ever more desperate and extravagant potlatch performances by those who aspired to authority (reliant on ever more unsustainable forms of exploitation).

\section{Conclusion}

Human modes of production were not eradicated but expanded and transformed by their interaction with capitalism. This was due to a dynamic where ecological, demographic and ritual imperatives fed off each other. As I have argued FMA scholarship did much to explain this situation, integrating ideas of history, class, and contested social reproduction with earlier functionalist and substantivist accounts of exchange. As we have also shown, the FMA formulation, like earlier anthropological accounts, tended to overstress marriage exchanges at the expense of a much wider jural and therapeutic ritual nexus. They also downplayed the role of theatre, aesthetics, and metaphysical beliefs in sustaining the power of elders and chiefs in a situation that was radically unstable. In a similar way ecological and demographic concerns need to be integrated into this schema - not at the expense of socio-cultural explanation but as part of a complex whole.

The striking similarity in the way that human modes of production reacted to their capitalist mode of production - not by the weakening of extant social logics but by a kind of social and ritual escalation we have called the potlatch - suggests that these phenomena are an aspect of global modernity. 


\section{References}

Anderson, Perry, 1980. Arguments within English Marxism. London: Verso.

Austin, Gareth. 2008. Resources, techniques, and strategies south of the Sahara: Revising the factor endowments perspective on African economic development, 1500-2000. Economic History Review 61(3): 587-624.

2008a. Resources, techniques, and strategies south of the Sahara: revising the factor endowments perspective on African economic development, 1500-2000. Economic History Review 61(3): 587-624.

Barber, Karin, 2007. 'When People Cross Thresholds'. African Studies Review Volume 50, Number 2, September 2007, pp. 111-123

Barth, F. 1956 Political leadership among Swat Pathans, London : University of London, the Athlone Press.

Barth, F 1959 Political leadership among Swat Pathans, London Athlone Press,.

Bernault, Florence. 2006. Body, power and sacrifice in equatorial Africa. Journal of African History 47: 207-239.

Blackburn, Robin. 1997. The making of new world slavery: From the Baroque to the modern, 1492-1800. Verso: London.

Bloch, M, 1985. Marxism and anthropology, the history of a relationship. Oxford: 
Oxford University Press.

Boas, Franz. 1916. Tsimshian mythology. Thirty-first annual report of the US Bureau of American Ethnology.

1925 'Contributions to the ethnology of the Kwakiutl.' Columbia University contributions to Anthropology, volume III. New York: Columbia University Press.

Bohannan Paul, 1959 'The impact of money on an African subsistence economy'. The Journal of Economic History, Vol. 19, No. 4 p. 491-503.

Boyd, Robert 1999. The coming of the spirit of pestilence : introduced infectious diseases and population decline among Northwest Coast Indians, 1774-1874 /. Vancouver Seattle: UBC Press.

Brenner, Paul 1977. 'The origins of capitalist development; a critique of neo-Smithian Marxism', New Left Review I/104, July-August 1977, pp. 25-92

Cooper, Frederick 2000. 'Africa's pasts and Africa's historians', Canadian Journal of African Studies Revue Canadienne des Études Africaines, Vol.34, No. 2, pp. 298-336

Cohen, Gerry 1978. Karl Marx's theory of history: a defence. Oxford and Princeton, Clarendon Press.

- 1982. 'Reply to Elster on "Marxism, functionalism, and game theory"'. Theory and Society, Vol. 11, No. 4 (Jul., 1982), pp. 483-495

Comaroff, Jean and Comaroff, John L. 2004. 'Afromodernity and the new world order' in Producing African futures : ritual and reproduction in a neoliberal age / edited by Brad Weiss. Leiden : Brill, 2004

de Heusch, Luc 2002. Du pouvoir: anthropologie politique des sociétés d'Afrique centrale, Nanterre: Société d'ethnologie. 
De Boeck, Filip 1999. 'Domesticating diamonds and dollars: identity, expenditure and sharing in southwestern Zaire' in Globalization and identity: dialectics of flow and closure (ed) Birgit Meyer and Peter Geschiere. Oxford:Blackwells.

Donald, Leland. 1997. Aboriginal slavery on the Northwest coast of North America. Berkeley: University of California Press.

Donham, Donald 1999. History, power, ideology: central issues in Marxism and anthropology Berkeley, Calif. ; London : University of California Press.

Douglas, Mary 1968. The Lele of the Kasai. London: International African Institute.

Dupré, Georges. 1985. Les naissances d'une société: Espace et historicité chez les Beembé du Congo. Paris: ORSTOM.

Dupré, Georges and Rey P-P. 1969 Réflexions sur la pertinence d'une théorie de l'historie des éxchanges, Cahiers Internationaux de Sociologie, Nouvelle Serie Vol. 46 (Janvier-juin 1969), pp. 133-162

Eltis, David, and Lawrence C. Jennings. 1998. Trade between Western Africa and the Atlantic world in the pre-colonial era. The American Historical Review 93(4): 936959.

Ferguson, Niall. 2002. The cash nexus: Money and power in the modern world, 17002000. London: Penguin.

Foucault, Michel 1998. The History of sexuality. Vol.1, The will to knowledge. Translated from the French by Robert Hurley. London; Penguin

Goody, Jack. 1958. The developmental cycle in domestic groups, London; Cambridge University Press

Graeber, David. Graeber, David 2001. Toward an anthropological theory of value: the 
false coin of our own dreams. New York, Palgrave.

- 2006 Turning modes of production inside out or, why capitalism is a transformation of slavery Critique of Anthropoligy 26 (1) pp 61-85.

- 2011. Debt: The first 5,000 years. New York: Melville House.

Guyer, Jane I, 1993. 'Wealth in people and self-realization in equatorial Africa' Man, New Series, Vol. 28, No. 2 (Jun.,), p. 243-265

- 1995. 'Introduction: the currency interface and its dynamics' in Money matters : instability, values, and social payments in the modern history of West African communities (ed.) Jane Guyer Portsmouth, N.H. and London: Heinemann

Hann Chris, and Keith Hart 2011. Economic Anthropology: History, Ethnography, Critique. Cambridge: Polity Press.

Harms, Robert W. 1981. River of wealth, river of sorrow: The central Zaire basin in the era of the slave and ivory trade, 1500-1891. New Haven and London: Yale University Press.

Hornby, Lucy 2015. 'Du Runsheng, Chinese farm reformer, 1913-2015' Financial Times, $6^{\text {th }}$ November.

Hochschild, Adam. 1998. King Leopold's ghost: A story of greed, terror, and heroism in colonial Africa. Boston: Houghton Mifflin.

Hochschild, Adam. 2005. In the heart of darkness. The New York Review of Books, 6 October.

Hochschild, Adam. 2006. Letter to the editor: Adam Hochschild replies (to Jean-Luc Vellut). The New York Review of Books, 12 January. 
Inikori, Joseph E. and Stanley L. Engerman, 1992. Introduction : gainers and losers in the Atlantic slave trade, in Joseph E. Inikori and Stanley L. Engerman (eds) The Atlantic slave trade : effects on economies, societies, and peoples in Africa, the Americas, and Europe. Durham, Duke.

Jewsiewicki, Bogumil 1985. Un débat, un paradigme, une épistémê (pp. 2-8) Canadian Journal of African Studies / Revue Canadienne des Études Africaines, Vol. 19, No. 1.

Kahn Joel. \& Josep R. Llobera 1980. 'French Marxist anthropology: twenty years after', The Journal of Peasant Studies, 8:1, 81-100.

Klien, Naomi 2007. The shock doctrine, the rise of disaster capitalism. London: Allen Lane.

Kuper, Adam 1988. The invention of primitive society. Transformations of an illusion. London : Routledge.

Leach, Edmund 1954. Political systems of highland Burma: A study of Kachin social structure. Cambridge Mas: Harvard University Press.

Laman, Karl Edvard. 1957. The Kongo, vol. 2. Uppsala and London: Uppsala Universitet and Kegan Paul.

Parry, Jonathan. 1986. The gift, the Indian gift and the "Indian gift." Man 21(3): 453447.

MacGaffey, Wyatt. On the Moderate Usefulness of Modes of Production Canadian Journal of African Studies / Revue Canadienne des Études Africaines, Vol. 19, No. 1 (1985), pp. 51-57

- 1986. Religion and society in central Africa: The BaKongo of lower Zaire. Chicago: University of Chicago Press. 
- 2000. Kongo political culture: The conceptual challenge of the particular.

Bloomington: Indiana University Press.

- 2005. 'Changing representations of African history'. The Journal of African History, Volume 46, (02), p 189-207.

Manning, Patrick 1990. Slavery and African life: occidental, oriental, and African slave trades African studies series; 67. Cambridge ; New York : Cambridge University Press,

- 1992. The slave trade : the formal demography of a global system in Joseph E. Inikori and Stanley L. Engerman (eds) The Atlantic slave trade : effects on Economies, Durham : Duke University Press.

Marx, K. 1867/1961. Capital: a critical analysis of capitalist production (Vol 1). Translated from the third German edition by Samuel Moore and Edward Aveling and edited by Frederick Engels. Moscow: Foreign Languages Publishing House.

- 1895/1991. Capital: a Critical Analysis of Capitalist Production, Volume III., with introduction by E. Mandel, trans. D. Fernbach. London: Penguin.

Meillasoux, Claude 1960. 'Essai d'interprétation du phénomène economique dans les sociétés traditionelles d'autosubsistance' Cahiers d'Etudes Africaines 4, p.38-67.

Nugent, Stephen. 2007. Some reflections on anthropological structural Marxism. Journal of the Royal Anthropological Institute, 13(2), pp. 419-431

Pietz, William. 1985. 'The Problem of the Fetish, I', Anthropology and Aesthetics, 9, pp. 5-17.

Rey, Pierre Philippe. 1971. Colonialisme, néo-colonialisme et transition au capitalisme: Exemple de la Comilog au Congo-Brazzaville. Paris: Maspero

Ringel, Gail. 1979. The Kwakiutl potlatch: History, economics, and symbols. 
Ethnohistory 26(4). 347-362.

Richter, Daniel. 1992. The ordeal of the longhouse: The peoples of the Iroquois League in the era of European colonization. Williamsburg: University of North Carolina Press.

Roes, Aldwin 2010. Towards a History of Mass Violence in the Etat Indépendant du Congo, South African Historical Journal, vol. 62, no. 4.

Roth, Christopher. 2002. Goods, names, and selves: Rethinking the Tsimshian potlatch source. American Ethnologist 29(1): 123-150.

Smith, Adam. (1776) 1904. An inquiry into the nature and causes of the wealth of nations. London: Methuen \& Co. Retrieved from www.econlib.org/library/Smith/smWNCover.html.

Terray, Emmanuel (ed) 1986. Afrique Plurielle, Afrique Actuelle Hommage a Georges Balandier. Paris; Katharla

Thomas, Nicholas. 1991. Entangled objects: Exchange, material culture, and colonialism in the Pacific. Cambridge, MA, and London : Harvard University Press.

Thompson, EP 1978. The Poverty of Theory and other essays. London; Merlin Press.

Tilly, Charles. 1985. Coercion, capital, and European states: AD 990-1992, Cambridge, MA: Blackwell.

Vansina, Jan. 1978. The children of Woot: A history of the Kuba peoples. Madison: University of Wisconsin Press.

- 2010. Being Colonized: the Kuba experience in rural Congo 1880-1960. Madison: University of Wisconsin Press. 
Veblen, Thorstein. (1899) 2001. Theory of the leisure class. London: Random House.

Vellut, Jean-Luc. 2004. Réflexions sur la question de la violence dans Afrique

Central. In Pamphile Mabiala Mantuba-Ngoma, ed., La nouvelle histoire du Congo:

Mélanges Eurafricains offerts à Frans Bontinck. Paris: L'Harmattan.

Vos, Jelmer. 2003. The economics of the Kwango rubber trade, c. 1900. International symposium Angola on the move: Transport routes, communication, and history, Berlin, 24-26 September.

Walens, Stanley. 1981. Feasting with cannibals: An essay on Kwakiutl cosmology.

Princeton, NJ: Princeton University Press.

Warnier, Jean-Pierre 2007. The pot-king: the body and technologies of power Leiden: Brill.

Wolf, Eric. 1997. Europe and the people without history. Berkeley: University of California Press.

Wolpe, Harold. 1972 'Capitalism and cheap labour power in South Africa: from segregation to Apartheid.' Economy and Society 1 : 425-56

White, Matthew 2011. 'The conquest of the Americas', Necrometrics, [online] available at:http://necrometrics.com/pre1700a.htm\#America. 